О.А. Винницька' ${ }^{1}$ Н.В. Дубей', О.І. Дорош², Л.я. Дубей'

${ }^{1}$ Львівський національний медичний університет імені Данила Галицького 23ахідноукраїнський спеціалізований дитячий медичний центр, Львів

\title{
Перспективи розвитку дослідження мутаційного статусу в дітей із гострими лімфобластними лейкеміями
}

Мета-визначити можливості стратифікації дітей із гострими лімфобластними лейкеміями (ГЛЛ) на прогностичні групи за допомогою молекулярно-генетичних методів діагностики ізольовано чи в комплексі з іншими стратифікаційними критеріями. Об'єкт і методи дослідження. Здійснено аналіз вибраної літератури за період 2010-2018 рр., що стосується проблематики прогнозування ефективності терапії у дітей із ГЛЛ як до, так і після рецидивів. Результати. На сьогодні застосування класифікації National Cancer Institute для стратифікації дітей на прогностичні групи є найпростішим і досить ефективним методом. Однак з урахуванням розвиткумолекулярногенетичних методів аналізу мутаційного статусу генів бластних клітин і публікації даних нових досліджень, що свідчать про ефективність застосування показників мутаційного статусу для детальної стратифікації дітей із ГЛЛ, комбіноване застосування цих показників дасть змогу покращити ефективність призначеного лікування відповідно до ризик-факторів у цих осіб. Наразі найбільш дослідженими і вагомими мутаціями, що впливають на прогноз у дітей із ГЛЛ, є мутації IKZF1, CDKN2A/B, NRAS/KRAS, TP53 та PAX5. При визначенні характеристик мутацій гена ABL1 у пацієнтів із транслокацією $t(9 ; 22) / B C R-A B L 1$ можна досягти кращої ефективності лікування ГЛЛ препаратами групи інгібіторів протеїнкіназ завдяки застосуванню найефективнішого препарату. Наявність певних мутацій може впливати на толерантність до препаратів стандартних протоколів терапії. Tак, мутації NR3C1/ BTG1 та CREBBP асоційовані з резистентністю до терапії глюкокортикоїдами, мутація NT5C2 - аналогами нуклеозидів. Після рецидиву ГЛЛ мутаційний статус бластних клітин може бути відмінним від його характеристик на етапі первинної діагностики й потребує повторного визначення. Висновки. Для поглибленої стратифікації дітей із ГЛЛ на прогностичні групи наразі потенційно найефективнішим методом є комбінація стандартних схем і визначення мутаційного статусу бластних клітин.

Ключові слова: гостра лімфобластна лейкемія, хромосомні трансформації, точкові мутації, молекулярно-генетичні методи діагностики.

\section{Вступ}

Гостра лімфобластна лейкемія (ГЛЛ) - найчастіше злоякісне неопластичне захворювання дитячого віку, що маніфестує здебільшого у осіб віком 3-6 років (Irving J.A. etal., 2016; Moorman A.V., 2016). Хоча етіологія ГЛЛ остаточно невідома, у $75 \%$ пацієнтів виявляють хромосомні трансформації, точкові мутації, варіації кількості копій генів (Irving J.A. etal., 2016; Moorman A.V., 2016). Зазначимо, що 25\% дітей становлять групу «інших гетерогенних ГЛЛ», в яких відсутні хромосомнітрансформації, однак не виключеніточкові мутації та варіації кількості копій генів (Moorman A.V., 2016). ГЛЛ у дітей займає 1-ше місце в рейтингу смертності від онкологічних захворювань (Vrooman L.M., Silverman L.B., 2016). Хлопчики хворіють на 40\% частіше, ніждівчатка (Moorman A.V., 2016), Т-клітинна ГЛЛ (15\% усіхГЛЛ) прогностично гірша порівняно з В-лінійною (Moorman A.V., 2016; Vrooman L.M., Silverman L.B., 2016; Brown P.A. et al., 2017).

Стандартна стратифікація прогностичних груп дітей із ГлЛ Національного інституту раку (National Cancer Institute - NCl) включає дві групи характеристик:

1) ті, що сприяють успішності базової терапії: вік 1-10 років, кількість лейкоцитів крові $<50 \cdot 10^{9} / л$, В-клітинна Глл, гіперплоїдія чи ETV6-RUNX1-хромосомна трансформація, мінімальна залишкова хвороба (МЗХ) не виявляються під час терапії або показники МЗХ незначні;

2) несприятливі чинники базової терапії: вік $>10$ років або $<1$ року, кількість лейкоцитів крові $\geqslant 50 \cdot 10^{9} / л$, Т-клітинна ГЛЛ, наявність таких хромосомних трансформацій, як транслокації KMT2A, t(9;22)/BCR-ABL1, t(17;19)/TCF3-HLF та AMP21, близька гаплоїдія (24-30 хромосом), низька гіподиплоїдія (31-39 хромосом), $t(1 ; 19) T C F 3 / P B X$, транслокації гена /GH, група інших В-ГЛЛ, виявлення МЗХ під час терапії (Ma X. et al., 2015; Vrooman L.M., Silverman L.B., 2016; Brown P.A. et al., 2017).

Хоча за допомогою класифікації $\mathrm{NCl}$ досягнуто значних успіхів у лікуванні, вона не є вичерпною; пропонується комбінований підхід до стратифікації прогностичних груп із використанням аналізу мутаційного статусу бластних клітин (Vora A. et al., 2014; Barbosa T.C. et al., 2015; Moorman A.V., 2016; Vrooman L.M., Silverman L.B., 2016; Brown P.A. et al., 2017; Pan L. et al., 2017; Sutton R. et al., 2018). Такий поглиблений аналіз мутаційного статусу дозволить вибрати найефективніше покоління препаратів, що показано на прикладі інгібіторів тирозинкіназ (Brown P. et al., 2017).

Мета - визначення можливостей стратифікації дітей із Глл у прогностичні групи за допомогою молекулярно-генетичних методів діагностики. Проведено огляд результатів сучасних наукових праць, в яких застосовували молекулярно-генетичні методи стратифікації дітей із ГлЛ ізольовано чи в комбінації з іншими методами стратифікації. Визначено майбутні перспективи розвитку молекулярно-генетичного підходу до діагностики Глл.

\section{Об'єкт і методи дослідження}

Здійснено аналіз літератури за період 2010-2018 рр., що стосується проблематики прогнозування ефективності терапії у дітей із ГЛЛ як до, так і після рецидивів.

\section{Результати та їх обговорення}

Генні трансформації можуть бути первинними (однакові в усіх лімфобластних клітинах хворої дитини (хромосомні трансформації) івторинними (різними в різних клонів лімфобластної клітини варіації кількості копій генів, точкові мутації). Первинні генні трансформації, такі як хромосомні транслокації та анеуплоїдія, ініціюють утворення прелейкемічного клону, який за умови набуття певних вторинних трансформацій може стати причиною ГЛЛ (Irving J.A. et al., 2016; Moorman A.V., 2016; Brown P.A. et al., 2017). Первинні генні трансформації визначають у $\approx 75 \%$ усіх випадків ГЛЛ (Ma X. et al., 2015).

Зауважимо, що прелейкемічні клони можуть знаходитись у латентному стані до 10 років і лише при набутті вторинної транс- 
формації - ініціювати Глл (Moorman A.V., 2016). Частота наявності хоча б однієї вторинної генної трансформації у пацієнтів із ГЛЛ коливається в межах 66-83\% (Barbosa T.C. et al., 2015; MaX. et al., 2015; Fang Q. et al., 2018; Kathiravan M. et al., 2018).

Важливо, що залежно від наявності певної первинної мутації можна прогнозувати виникнення конкретних вторинних. Так, під час транслокацій IGH виникають вторинні мутації IKZF1 або $C D K N 2 A / B$, а при $t(9 ; 22) / B C R-A B L 1$ можуть виникнути мутації $C D K N 2 A / B$ та $P A X 5$ (Ma X. et al., 2015; Moorman A.V. 2016; Kathiravan M. et al., 2018).

Хоча первинні генні трансформації вважають прогностично більш значущими порівняно зі вторинними, все більше досліджень спрямовані на розроблення моделей прогнозування на основі комбінованої оцінки первинних і вторинних трансформацій, що може покращити точність стратифікації дітей із ГлЛ (Ma X. et al., 2015; Irving J.A. et al., 2016; Moorman A.V., 2016; Heerema N.A., Raimondi S.C., 2018).

Двома найголовнішими первинними хромосомними трансформаціями у дітей є транслокація t(12;21) (p13;q22/ETV6-RUNX1) і гіпердиплоїдія (51-67 хромосом), що разом складають етіологію до 60\% ГлЛ (25 і 35\% відповідно). Такі первинні трансформації, як транслокації $t(1 ; 19) T C F 3 / P B X$, гена /GH і група інших В-клітинних ГЛЛ, асоційовані з проміжним ризиком неуспішності терапії (Moorman A.V., 2016; Heerema N.A., Raimondi S.C., 2018). Ïх відмічають у 20-25\% усіх випадків ГлЛ (Ma X. et al., 2015).

Подальша стратифікація ризику додатковими методами в цій групі вкрай важлива. Стратифікація дітей із ГлЛ всередині проміжної групи ризику на групи з кращим і гіршим прогнозом може бути виконана за допомогою визначення мутаційного статусу.

Найчастішими вторинними мутаціями є мутації генів CDKN2A/2B, PAX5, ETV6 та IKZF1 (Ma X. et al., 2015). Так, делеція $C D K N 2 A / B$ у дітей із ГЛЛ незалежно асоційована з гіршою загальною виживаністю і частішими ранніми рецидивами порівняно з контрольною групою дітей без мутації (Kathiravan M. et al., 2018). Однак все більше вчених підтверджують роль і інших мутацій для детальної стратифікації прогностичних груп (Wang J. et al., 2015; Yohe S., 2015; Dafflon C. et al., 2017; Fang Q. et al., 2018).

Як зазначено вище, аналіз мутаційного статусу має найбільшу цінність для стратифікації групи проміжного і високого ризику. Так, наявність злиття генів P2RY8-CRLF2 у дітей зі стандартним або проміжним ризиком, визначеним за стандартною схемою, значно погіршувало прогноз рецидиву у дослідженні C. Dafflon та співавторів (2017). Крім того, у дорослих пацієнтів визначали вплив на прогноз терапії таких варіацій числа копій генів: IKZF1, CDKN2A/2B, PAX5, RB1, BTG1. Пацієнти з більше ніж трьома зазначеними варіаціями копій генів мали значуще нижчі прогностичні показники порівняно з іншими групами (Fang Q. et al., 2018)

Необхідність у визначенні нових чинників, що можуть впливати на прогноз перебігу ГЛЛ, підтверджується позитивними результатами дослідження, в якому комплексна математична оцінка 14 прогностичних факторів 3 81\% точністю стратифікувала пацієнтів із ГЛЛ на прогностичні групи (Pan L. et al., 2017). До того ж комбінація двох методів стратифікації ризику ( $\mathrm{NCl}$ і методу визначення числа копій генів) дозволила підвищити 5-річну виживаність внаслідок деінтенсифікації терапії у певних груп дітей (Moorman A.V. et al., 2014).

Наявність МЗХ на 4-5-й тиждень від початку лікування є вагомим незалежним прогностичним маркером неуспішності протоколу терапії та високої імовірності рецидиву (Vora A. et al., 2014; Vrooman L.M., Silverman L.B., 2016). Наразі існує багато доказів щодо використання наявності МЗХ як основного прогностичного маркера при застосуванні різних протоколів лікування (Vora A. et al., 2014; Vrooman L.M., Silverman L.B., 2016; Gupta S.K. et al., 2017; Sutton R. et al., 2018). Так, інтенсифікація терапії у дітей стандартного і проміжного ризику, в яких виявили МЗХ, значно покращує подальший прогноз (Vora A. et al., 2014).

Застосовуючи прогностичну класифікацію на основі MЗX, вдалося досягнути покращення показників 5-річної виживаності дітей зі стандартним і проміжним прогнозом ГЛЛ з 76 до 88\% за допомогою інтенсифікації терапії (Gupta S.K. et al., 2017). У пацієнтів із високим ризиком за допомогою інтенсифікації хіміотерапії і трансплантації стовбурових клітин 5-річна виживаність підвищилася від історичних 16 до 78\% (Gupta S.K. et al., 2017).
Однак для дітей із МЗХ у межах 0-5\% потрібні інші додаткові стратифікаційні методи для більш точного прогнозування, оскільки такий діапазон МЗХ не має достатньої прогностичної сили. Отже, вдалося виділити межі МЗX 0,01-0,1\% у пацієнтів із цитогенетично сприятливим ризиком, при яких хворі не потребують інтенсифікації терапії та добре відповідають на стандартний протокол лікування (Kathiravan M. et al., 2018).

R. Sutton та співавторами (2018) запропоновано нову комбіновану систему стратифікації прогнозу рецидиву ГЛЛ у дітей зі стандартним та проміжним ризиком неуспішності терапії згідно зі стандартною класифікацією $\mathrm{NCl}$. Ця нова схема включає показники наявності делеції гена IKZF1, злиття генів P2RY8-CRLF2, віку, кількості лейкоцитів у крові, наявності МЗХ на 33-й день терапії. Схема дозволяє виділити три прогностичні групи - ризик 0; 1 та 2+ - зі статистично різними показниками безрецидивної виживаності та загальної виживаності 93; 78; 49 та 99; 91; 71\% відповідно.

Гіперекспресія генів CAMSAP1, PCGF6, SH3RF3 позитивно корелювала з ефективністю стандартної терапії ГЛЛ, а гіперекспресія генів AK022211, FASTKD1, STARD4 асоційована з негативними результатами терапії. J. Wang та співавтори (2015) запропонували класифікацію пацієнтів із прогнозовано позитивним і негативним результатами лікування, а саме: пацієнти з 1 негативним i $<2$ позитивними генами і хворі $3 \geqslant 2$ негативними генами незалежно від кількості позитивних становили групу високого ризику неуспішності лікування; особи $3 \leqslant 1$ негативним $\mathrm{i} \geqslant 2$ позитивними генами становили групу низького ризику неуспішності терапії. Цікаво, що ця методика стратифікації пацієнтів показала ефективність у поєднанні з цитогенетичною стратифікацією, наявністю M3X і гіперекспресією гена CRLF2, поглиблюючи їх прогностичну цінність.

Стратегія лікування у пацієнтів із ГлЛ має бути переглянута після рецидиву (Hunger S.P., Mullighan C.G., 2015; Brown P.A. et al., 2017; Sutton R. et al., 2018). Навіть якщо лікування за стандартними протоколами було успішним на стадії первинної маніфестації хвороби, застосування того самого протоколу для лікування у разі рецидиву не завжди ефективне (Hunger S.P., Mullighan C.G., 2015; Brown P.A. et al., 2017; Sutton R. et al., 2018). Прогнозувати успіх подальшої терапії після рецидиву можна за допомогою трьох показників:

1) тривалість першої ремісії;

2) локалізація осередка ремісії (медулярне чи екстрамедулярне);

3) за допомогою визначення імунофенотипу. У результаті комплексного застосування цих трьох показників виділяють групу високого, проміжного і стандартного ризиків неуспішності стандартної схеми терапії після рецидиву. Визначено, що пацієнти з цитогенетично високим ризиком неуспішності терапії мають лікуватися згідно з інтенсифікованим протоколом як до, так і після рецидиву, незважаючи на клінічно визначену прогностичну групу (Irving J.A. et al., 2016; Moorman A.V., 2016). Діти із клінічно стандартним або проміжним ризиком і цитогенетично низьким ризиком добре відповідають на стандартні схеми терапії, а пацієнти із клінічно високим ризиком і цитогенетично низьким ризиком неуспішності терапії часто мають мутації шляху RAS (особливо діти з гіпердиплоїдією), що істотно погіршує прогноз перебігу ГлЛ після рецидиву (Irving J.A. et al., 2016).

Зважаючи на те що первинні генні трансформації зберігаються після рецидиву ГлЛ, однак відповідь на терапію часто змінюється, головним предиктивним фактором у групі дітей після рецидиву хвороби можна вважати саме вторинні генні трансформації. Важливо, що вторинні мутації після рецидиву змінюються, і ті, що визначені на етапі первинної діагностики, часто зникають, і виникають нові. Так, визначення мутаційного статусу дозволяє найточніше стратифікувати дітей на нові прогностичні групи після рецидиву ГЛЛ (Irving J.A. et al., 2016; Brown P.A. et al., 2017).

Делеція IKZF1 (15-17\% усіхГЛЛ) - найчастіша післярецидивна вторинна мутація, що асоційована з гіршими результатами терапії і може застосовуватися для стратифікації дітей у групи високого ризику незалежно від інших систем, що виявлено у дослідженнях (Clappier E. et al., 2015; Boer J.M. et al., 2017; Kathiravan M. et al., 2018; Sutton R. et al., 2018). 
Крім того, є дані про позитивні результати терапії дітей із делецією IKZF1 пульс-терапією вінкристином у комплексі з глюкокортикоїдами додатково до стандартного протоколу (Clappier E. et al., 2015). Однак в інших наукових працях демонструється, що після рецидиву незалежна негативна прогностична чинність IKZF1 втрачається (наприклад у дітей із первинною трансформацією ETV6-RUNX1) і залежить від інших вторинних мутацій (Irving J.A et al., 2016; Brown P.A. et al., 2017). Мутація TP53 в усіх прогностичних групах асоційована з поганим прогнозом успішності терапії після рецидиву (Irving J.A. et al., 2016). Делеція NR3C1/BTG1 асоційована з резистентністю до терапії глюкокортикоїдами і корелює з гіршими результатами комбінованої терапії. В іншому дослідженні мутація NT5C2 визнана причиною резистентності до аналогів нуклеозидів, а мутація CREBBP - до глюкокортикоїдів (Brown P.A. et al., 2017). Мутації NRAS/KRAS у дітей із гіпердиплоїдією незалежно від клінічно визначеної прогностичної групи підвищують смертність у 3-5 разів. Зазначимо, що залежно від прогностичної групи, визначеної стандартним методом, вплив цієї мутації на загальну смертність був вищим у групі високого ризику порівняно із групою стандартного ризику. Загалом результати дослідження підтверджують необхідність використання комбінованого підходу до стратифікації прогностичних груп дітей з ГЛЛ (Irving J.A. et al., 2016).

Пацієнтам із поганим післярецидивним прогнозом показана терапія алогенними гематопоетичними стовбуровими клітинами (Vora A. et al., 2014; Hunger S.P., Mullighan C.G., 2015). Однак, зважаючи на значні побічні явища і високу вартість цього лікування, важливим завданням сучасної онкогематології $є$ розроблення найефективніших прогностичних моделей для верифікації серед дітей із високим ризиком таких, що можуть бути вилікувані більш безпечною та дешевшою хіміотерапією.

\section{Висновки}

Точна стратифікація дітей із ГЛЛ на прогностичні групи успішності терапії є пріоритетним напрямом сучасних досліджень онкогематології та педіатрії. Стандартні методи стратифікації дітей не можуть цілком задовольнити потреби сучасної науки. Це зумовлено насамперед наявністю широкого спектра нових альтернативних хіміо- та імунотерапевтичних препаратів, що мають високу ефективність в окремих групах пацієнтів. Детальне визначення цих груп може покращити ефективність лікування дітей із проміжним і високим ризиком терапії, що часто погано відповідають на прийняті протоколи терапії.

Для поглибленої стратифікації дітей на прогностичні групи наразі потенційно найбільш ефективним методом є комбінація стандартної схеми і визначення мутаційного статусу бластних клітин. Попри наявність наукових праць, у яких розкриваються можливості окремого застосування мутаційного статусу для стратифікації дітей, незважаючи на інші методи, доказів ефективності такого підходу на великих когортах гетерогенних пацієнтів не виявлено. Насамперед це зумовлено недостатньою кількістю знань щодо впливу кожної окремої мутації та їх комбінації на прогнО3.

Вплив таких вторинних мутацій, як IKZF1, CDKN2A/B, NRAS/ KRAS, TP53, PAX5, на прогноз терапії у дітей із ГЛЛ на сьогодні $\Theta$ найбільш дослідженим. Розроблення схем інтеграції цих та інших показників мутаційного статусу лімфобластних клітин у стандартні схеми стратифікації дітей на прогностичні групи може поглибити стратифікацію і покращити результати лікування.

\section{Список використаної літератури}

Barbosa T.C., Terra-Granado E., Quezado Magalhães I.M. et al. (2015) Frequency of copy number abnormalities in common genes associated with B-cell precursor acute lymphoblastic leukemia cytogenetic subtypes in Brazilian children. Cancer Genet., 208(10): 492-501.

Boer J.M., Steeghs E.M., Marchante J.R. et al. (2017) Tyrosine kinase fusion genes in pediatric $B C R-A B L 1$-like acute lymphoblastic leukemia. Oncotarget. 8(3): 4618-4628

Brown P.A., Shah B., Fathi A. et al. (2017) NCCN Guidelines Insights: Acute Lymphoblastic Leukemia, Version 1.2017. J. Natl. Compr. Canc. Netw., 15(9): 1091-1102.

Clappier E., Grardel N., Bakkus M. et al.; European Organisation for Research and Treatment of Cancer, Children's Leukemia Group (EORTCCLG) (2015) IKZF1 deletion is an independent prognostic marker in childhood B-cel precursor acute lymphoblastic leukemia, and distinguishes patients benefiting from pulses during maintenance therapy: results of the EORTC Children's Leukemia Group study 58951. Leukemia, 29(11): 2154-2161.

Dafflon C., Craig V.J., Méreau H. et al. (2017) Complementary activities of DOT1L and Menin inhibitors in MLL-rearranged leukemia. Leukemia, 31(6): 1269-1277.

Fang Q., Yuan T., Li Y. et al. (2018) Prognostic significance of copy number alterations detected by multi-link probe amplification of multiple genes in adult acute lymphoblastic leukemia. Oncol. Lett., 15(4): 5359-5367.

Gupta S.K., Bakhshi S., Kumar L. et al. (2017) Gene copy number alteration profile and its clinical correlation in B-cell acute lymphoblastic leukemia. Leuk. Lymphoma, 58(2): 333-342.

Heerema N.A., Raimondi S.C. (2018) Cytogenetics of Acute Leukemia. In: P. Wiernik, J. Dutcher, M. Gertz (Eds.). Neoplastic Diseases of the Blood. Springer, Cham.

Hunger S.P., Mullighan C.G. (2015) Acute Lymphoblastic Leukemia in Children. N. Engl. J. Med., 373(16): 1541-1552.

Irving J.A., Enshaei A., Parker C.A. et al. (2016) Integration of genetic and clinical risk factors improves prognostication in relapsed childhood B-cell precursor acute lymphoblastic leukemia. Blood, 128(7): 911-922.

Kathiravan M., Singh M., Bhatia P. et al. (2018) Deletion of CDKN2A/B is associated with inferior relapse free survival in pediatric $B$ cell acute lymphoblastic leukemia. Leuk. Lymphoma, Jul. 3 [Epub. ahead of print].

Ma X., Edmonson M., Yergeau D. et al. (2015) Rise and fall of subclones from diagnosis to relapse in pediatric B-acute lymphoblastic leukaemia. Nat. Commun., 6: 6604

Moorman A.V. (2016) New and emerging prognostic and predictive genetic biomarkers in B-cell precursor acute lymphoblastic leukemia. Haematologica, 101(4): 407-416.

Moorman A.V., Enshaei A., Schwab C. et al. (2014) A novel integrated cytogenetic and genomic classification refines risk stratification in pediatric acute lymphoblastic leukemia. Blood, 124(9): 1434-1444.

Pan L., Liu G. , Lin F. et al. (2017) Machine learning applications for prediction of relapse in childhood acute lymphoblastic leukemia. Sci. Rep., 7(1): 7402.

Sutton R., Venn N.C., Law T. et al. (2018) A risk score includeing microdeletions improves relapse prediction for standard and medium risk precursor B-cell acute lymphoblastic leukaemia in children. Br. J. Haematol., 180(4): 550-562.

Vora A., Goulden N., Mitchell C. et al. (2014) Augmented post-remission therapy for a minimal residual disease-defined high-risk subgroup of children and young people with clinical standard-risk and intermediate-risk acute lymphoblastic leukaemia (UKALL 2003): a randomised controlled trial. Lancet Oncol., 15(8): 809-818.

Vrooman L.M., Silverman L.B. (2016) Treatment of Childhood Acute Lymphoblastic Leukemia: Prognostic Factors and Clinical Advances. Curr. Hematol. Malig. Rep., 11(5): 385-394.

Wang J., Mi J.Q., Debernardi A. et al. (2015) A six gene expression signature defines aggressive subtypes and predicts outcome in childhood and adult acute lymphoblastic leukemia. Oncotarget., 6(18): 16527-16542.

Yohe S. (2015) Molecular Genetic Markers in Acute Myeloid Leukemia. J. Clin. Med., 4(3): 460-478.

\section{Перспективы развития исследования мутационного статуса у детей с острыми лимфобластными лейкемиями}

\section{Е.А. Винницкая, Н.В. Дубей, О.И. Дорош, Л.Я. Дубей}

Резюме. Цель - определить возможности стратификации детей с острым лимфобластным лейкозом (ОЛЛ) на прогностические группы с помощью молекулярно-генетических методов диагностики изолировано или в комплексе с другими стратификационными критериями. Объект и методы исследования. Осуществлен анализ литературы за период 2010-2018 гг. касаемо проблематики прогнозирования эффективности терапии у детей с ОЛЛ как до, так и после рецидивов. Результаты. На сегодняшний день применение классификации National Cancer Institute для стратификации детей на прогностические группы является наиболее простым и достаточно эффективным методом. Однако с учетом развития молекулярно-генетических методов анализа мутационного статуса генов бластных клеток и публикацию данных новых исследований, показывающих эффективность применения показателей мутационного статуса для детальной стратификации детей с ОЛЛ, комбинированное использование этих показателей позволит улучшить эффективность применяемого лечения в соответствии с риск-факторами уэтих лиц. Сейчас наиболее исследованными и весомыми мутациями, влияющими на прогноз у детей с ОЛЛ, являются мутации IKZF1, CDKN2A/B, NRAS/KRAS, TP53 и PAX5. При определении характеристик мутаций гена $A B L 1$ у пациентов с транслокацией $t(9 ; 22) / B C R-A B L 1$ можно достичь лучшей эффективности лечения ОЛЛ препаратами группы 
ингибиторов протеинкиназы благодаря применению наиболее эффективного препарата. Наличие определенных мутаций может влиять на толерантность к препаратам стандартных протоколов терапии. Так, мутации NR3C1/BTG1 и CREBBP ассоциированы с резистентностью к терапии глюкокортикоидами, мутация NT5C2 - аналогами нуклеозидов. После рецидива ОЛЛ мутационный статус бластных клеток может отличаться от его характеристик на этапе первичной диагностики и требовать повторного определения. Выводы. Для углубленной стратификации детей с ОЛЛ на прогностические группы пока потенциально наиболее эффективным методом является комбинация стандартных схем и определения мутационного статуса бластных клеток.

\section{Prospects of the development of the mutation status in children with acute lymphoblastic leukemia \\ O.A. Vynnytska, N.V. Dubey, O.I. Dorosh, L.Ya. Dubey}

Summary. Objectives - to determine the potential of stratification of children with acute lymphoblastic leukemia (ALL) into prognostic groups using molecular genetic diagnostic techniques apart or in combination with other stratification methods. Materials and methods. The analysis of the chosen literature of years 2010-2018 concerning the problems of prognostication of the effectiveness of treatment in children with ALL at initial diagnosis and after relapse has been performed. Results. To use National Cancer Institute classification for stratifying children into prognostic groups is the most simple and effective method. However, accord- ing to the development of molecular genetic methods to analyze the mutational status of genes, and according toverity of publications dedicated to new strategies to use mutational status parameters for detailed stratification of children with ALL, the combined approach may improve the accuracy of prognosis of treatment. Currently, the most studied and significant mutations affecting the prognosis of children with ALL are IKZF1, CDKN2A/B, NRAS/KRAS, TP53 and PAX5 mutations. Moreover, by identifying the characteristics of the ABL1 gene mutations in patients with translocation $t(9 ; 22) / B C R-A B L 1$, it is possible to achieve better treatment of ALL with protein kinase inhibitors by assigning the most effective generation of the drug. The presence of certain mutations can induce tolerance to certain components of standard scheme of treatment. Thus, NR3C1/BTG1 and CREBBP mutations may be associated with resistance to glucocorticoid therapy and NT5C2 - to nucleoside analogues in children with ALL. After the relapse of ALL, the mutational status of the blast cells is different from its characteristics at the stage of primary diagnosis and should be re-determined. Conclusion. The potentially effective approache for the accurate and comprehensive stratification of children with ALL into prognostic groups is the combine standard scheme and mutational status parameters.

\section{Адреса для листування:}

Винницька Олена Андріївна

79000, м. Львів, вул. Пекарська, 69

Львівський національний медичний

університет імені Данила Галицького

Одержано 11.09.2018 